\title{
Asimetri kekuasaan: Paradoks manajemen kolaborasi pengelolaan Danau Tempe Sulawesi Selatan
}

\author{
Power asymmetry: The paradox of collaborative management in management of Tempe Lake, \\ South Sulawesi
}

\author{
Muhammad Said ${ }^{\mathrm{a}}$ \\ ${ }^{a}$ Sekolah Tinggi Ilmu Sosial dan Ilmu Politik (STISIP) Petta Baringeng Soppeng, Jalan Poros Salaonro, Lilirilau Kabupaten \\ Soppeng, 90871, Indonesia [+62 85255988264]
}

Article Info:

Received: 30 - 12 - 2020

Accepted: 01 - 04 - 2021

Keywords:

Collaborative management, lake tempe, power asymmetry

Corresponding Author:

Muhammad Said

Sekolah Tinggi Ilmu Sosial dan Ilmu Politik (STISIP) Petta

Baringeng Soppeng;

Tel. +6285255988264

Email:

muhammad.said@mail.ugm.ac.id

\begin{abstract}
This paper aims to explain the power asymmetry as a paradox in collaborative management (co-management) of natural resources in Lake Tempe, South Sulawesi. This study uses a qualitative research method with an explanative case study approach. Data collection using participatory observation and in-depth interviews. The key informants came from elements of local government, big-scale fishermen, traditional fishermen, farmers, traders, and NGOs. The study results concluded that asymmetry or power imbalances between actors marked the management of Lake Tempe. Big-scale fisherman actors and the local government control the means of production, dominate the production of policies and determine the main determinants of the management of Lake Tempe compared to traditional (small-scale) fishers. The asymmetry of power between these actors impacts the imbalance in the benefits and value of resource allocation in Lake Tempe. Big Fisherman Actors and Local Governments get more benefits and value from natural resources. Meanwhile, traditional fishermen actors get fewer benefits and value from natural resources. In a particular stage, the conventional fishermen actors experience a process of marginalization.
\end{abstract}

How to cite (CSE Style $8^{\text {th }}$ Edition):

Said M. 2021. Asimetri kekuasaan: Paradoks manajemen kolaborasi pengelolaan Danau Tempe Sulawesi Selatan. JPSL 11(2): 241249. http://dx.doi.org/10.29244/jpsl.11.2.241-249.

\section{PENDAHULUAN}

Riset-riset terdahulu menyatakan bahwa pengelolaan sumber daya alam milik bersama (common pool resource), kawasannya melintasi batas-batas administratif wilayah, sulit dikuasai (high exlusion) dan banyak aktor yang menginginkannya (high substractability), lebih tepat mengaplikasikan pendekatan co-management (Ostrom, 1990; Bodin et al., 2006; Bodin dan Crona, 2008; Berkes, 2009). Common pool resource yang dinamis dan kompleks tidak tepat lagi dikelola oleh lembaga tunggal (pemerintah) dengan pendekatan command and control serta top-down approach, namun penting melibatkan kerjasama dan kemitraan antara aktor negara dan aktor non-negara: swasta dan warga lokal (Bodin et al., 2006; Berkes, 2009; Bodin dan Crona, 2008; Bodin dan Crona, 2009). Co-management adalah suatu proses dimana kita dapat mengatasi tantangan dan peluang diantara beberapa pelaku yang berada di dalam dan di luar lembaga formal termasuk di dalam proses pengambilan keputusan (Armitage et al., 2009; Carlsson dan Sandström, 2008; Berkes, 2009; Sandström dan Rovai, 2010; Yamaki, 2014). Bahkan Armitage et al. (2007) lebih jauh lagi mengembangkan 
konsep co-management dengan menambahkan konsep adaptive co-management, yaitu proses pengelolaan yang memfasilitasi berbagai aktor dari berbagai kalangan untuk membangun saling kepercayaan, pengembangan kelembagaan, pembelajaran sosial, dan tindakan kolektif untuk memecahkan masalah-masalah bersama dan melakukan perubahan yang inovatif secara terus-menerus. Adaptive co-management menyarankan pentingnya mengintegrasikan narasi pengetahuan modern yang dibangun oleh ahli dan negara dengan pengetahuan lokal lingkungan hidup yang hidup, dipercaya dan dikembangkan secara tradisional dan turun-temurun oleh warga lokal (Armitage et al., 2007).

Tipologi Danau Tempe dikategorikan sebagai sumber daya alam milik bersama (common pool resource) yang melimpah. Danau ini menjadi arena perebutan kepentingan antar aktor dan antar sektor. Aktor saling berebut akses dan kontrol dalam pengelolaan dan pemanfaatan SDA Danau Tempe. Sektor utama yang diperebutkan dalam konteks kebijakan pengelolaan adalah: Pertama, orientasi dan adopsi kebijakan, apakah berorientasi pada perikanan air tawar ataukah pertanian-perkebunan dalam penentuan mekanisme pengelolaan Danau Tempe (fishery oriented vs agriculture oriented); Kedua, sumber-sumber daya alam yang ada di Danau Tempe, yang utama adalah areal penangkapan ikan air tawar dan areal pertanian-perkebunan.

Perebutan aktor dan sektor ini dicirikan dengan adanya "over carrying capacity", permintaan pemanfaatan yang melampaui kapasitas sumber daya alam yang dimiliki Danau Tempe. Akibatnya, Danau Tempe dari hari ke hari mengalami degradasi dan kelangkaan (Said et al., 2019). Data SLHI (2012) menunjukkan kondisi fisik Danau Tempe berstatus Hipertrofik. Kualitas airnya mengandung kadar unsur hara sangat tinggi akibat tercemar unsur Nitrogen dan Fosfor yang sangat berat. Pendangkalan semakin meningkat akibat sedimentasi dari hulu dan munculnya tanaman eceng gondok yang semakin meluas. Terjadinya ketidakseimbangan antara sedimentasi yang masuk (inlate) dari DAS Wallanae dan DAS Bila dan yang ke luar (outlate) ke DAS Cenranae-Bone. Terjadinya kelangkaan ikan endemik, misalnya ikan betutu atau dalam Bahasa Bugis lebih dikenal bale bungo', dipercaya warga lokal sebagai ikan penambah stamina laki-laki, mulai berkurang, menyusut dan bahkan dalam waktu tertentu sudah menghilang.

Aktor yang terlibat dalam pengelolaan Danau Tempe memiliki sumber daya (modal) yang berbeda, bertingkat dan berlapis. Relasi antar aktor dalam pengelolaan Danau Tempe senantiasa diwarnai oleh kontestasi kepentingan dan kekuasaan (uang, sosial, simbolik dan kultural). Aktor yang memiliki kekuasaan yang lebih besar (powerful) mendominasi pengambilan keputusan, penentuan orientasi pembangunan, penentuan peraturan, dan penentuan distribusi sumber daya alam Danau Tempe. Sementara, aktor yang memiliki kekuasaan yang lebih kecil (powerless) termarginalisasi dari akes dan kontrol terhadap pengelolaan Danau Tempe. Aksi kolektif yang diharapkan dari co-management sangat sulit terjadi karena terfragmentasi dan terkooptasi oleh segelintir elit yang mengambil keputusan berdasarkan kepentingan dan keuntungan pribadi dan kelompoknya. Di titik ini, ditemukan berlangsungnya ketimpangan kekuasaan atau asimetri kekuasaan yang mengakibatkan penguasaan elit (elite capture) dalam proses dan pemanfaatan sumber daya alam di Danau Tempe.

Tulisan ini bertujuan menjelaskan proses berlangsungnya asimetri kekuasaan sebagai paradoks dalam pengelolaan bersama sumber daya alam di Danau Tempe Sulawesi Selatan. Asimetri Kekuasaan yang dimaksud dalam penelitian ini adalah ketimpangan atau ketidaksetaraan berbagai jenis sumber daya atau modal (uang, pengetahuan, sosial, budaya atau otoritas politik) dari seluruh aktor yang terlibat dalam pengelolaan Danau Tempe. Penggunaan asimetri kekuasaan dari kelompok aktor powerful dapat menyingkirkan kelompok aktor powerless dalam praktik pengelolaan dan pemanfaatan Danau Tempe. Studi ini penting dilakukan untuk memetakan asimetri kekuasaan antar aktor dan proses berlangsungnya asimetri kekuasaan dalam pengelolaan sumber daya alam di Danau Tempe. Hasil penelitian ini diharapkan dapat berkontribusi dalam melakukan intervensi kebijakan pengelolaan Danau Tempe secara inklusif dengan melakukan pemberdaayaan bagi kelompok aktor powerless (kelompok rentan di Danau Tempe: nelayan kecil). Pemberdayaan (empowernment) bagi nelayan kecil yang memilki sumber daya lemah meningkatkan partisipasi dan kesetaraan demgan aktoraktor lainnya dalam pengelolaan bersama (co-management) untuk meningkatkan ketahanan sosial, ekonomi dan lingkungan di Danau Tempe secara berkelanjutan. 


\section{METODE}

Penelitian ini merupakan penelitian kualitatif dengan pendekatan studi kasus eksplanatif (Yin, 2006). Data yang dikumpulkan adalah informasi dalam bentuk deskripsi detail dan interpretasi makna dari hasil wawancara dan pengamatan terlibat di lapangan. Data dianalisis untuk menjelaskan berlangsungnya asimetri kekuasaan antar aktor dalam pengelolaan Danau Tempe di Sulawesi Selatan.

\section{Metode Pengumpulan Data}

Teknik pengumpulan data dalam penelitian ini adalah: Pertama, wawancara mendalam kepada informan kunci yang mewakili unsur Pemerintah, nelayan besar, nelayan tradisional, pedagang, dan LSM. Penentuan informan kunci dilakukan dengan menggunakan teknik snow-ball sampling, yaitu penggalian data dan informasi kepada informan yang mengetahui konteks penelitian melalui wawancara mendalam dari satu informan ke informan lainnya dan seterusnya sampai peneliti tidak menemukan data dan informasi baru lagi (Hamidi, 2010). Teknik kedua, adalah dengan melakukan pengamatan terlibat (participatory observation) yang melihat secara langsung dan mendalam proses, konteks dan relasi sosial antar aktor dalam pengelolaan Danau Tempe.

\section{Metode Analisis Data}

Data-data yang terkumpul (berupa transkrip wawancara, catatan lapangan, hasil observasi, foto dokumentasi, gambar dan laporan-laporan media) dianalisis melalui langkah-langkah pengujian, pengkategorian, pentabulasian ataupun pengombinasian kembali bukti-bukti untuk menunjuk proposisi awal suatu penelitian. Proposisi awal penelitian ini adalah adanya kecurigaan terjadinya asimetri kekuasaan dalam proses pengelolaan kolaboratif Danau Tempe, sehingga menuntut pembuktian di kesimpulan akhir penelitian ini.

\section{HASIL DAN PEMBAHASAN}

Danau Tempe merupakan danau purba yang terletak di Provinsi Sulawesi Selatan. Danau ini menempati tiga wilayah Kabupaten yaitu Kabupaten Wajo, Soppeng dan Sidenreng Rappang. Luas Danau pada puncak musim hujan bisa mencapai kira-kira 47800 ha pada ketinggian 10 mdpl dengan luas daerah tangkapan air (catchment area) seluas $4587 \mathrm{~km}^{2}$. Kedalaman air sekitar $3 \mathrm{~m}$ ketika musim hujan dan $1 \mathrm{~m}$ ketika musim kemarau (SLHI, 2012). Danau ini umumnya dimanfaatkan sebagai areal penangkapan ikan air tawar oleh nelayan dan areal pertanian, perkebunan dan pemukiman warga di areal pinggiran danau. Di samping itu, Danau Tempe memiliki keanekaragaman hayati jenis satwa langka (ikan endemik dan burung-burung migran), sumber cadangan air baku irigasi pertanian, sumber air minum, destinasi pariwisata air, sumber air bagi penambangan gas alam, dan kepentingan konservasi.

Berdasarkan letak geografisnya, Danau Tempe merupakan satu kawasan ekosistem sumber daya alam yang terhubung dan terintegrasi di 3 Kabupaten (Wajo, Soppeng dan Sidrap). Pemanfaatan Danau Tempe dari masa ke masa mengikuti pola pasang surut air. Ketika air pasang di musim hujan, areal lahan Danau Tempe tergenangi air, warga lokal memanfaatkan sebagai areal penangkapan ikan. Ketika air surut di musim kemarau, areal lahan di bagian pesisir berubah menjadi areal pertanian, warga lokal memanfaatkan dengan cara menanam berbagai tanaman palawija dan buah-buahan. Dengan mengikuti pola pasang surut air, maka secara umum mata pencaharian warga lokal di Danau Tempe adalah nelayan dan petani. Disebut nelayan ketika mereka mengusahakan penangkapan ikan dan disebut petani ketika mereka mengelola areal pertanian. Kebanyakan warga lokal mengklasifikasikan dirinya menjalani "profesi ganda" yaitu sebagai nelayan sekaligus sebagai petani. 
Dengan pola pasang-surut air dari masa ke masa menjadi alasan sebagian besar warga lokal menentang kebijakan pembangunan dan pengoperasian Bendungan Gerak di Danau Tempe. Bendungan Gerak dibangun sejak tahun 2012 dan mulai beroperasi pada tahun 2013 oleh Balai Besar Wilayah Sungai PompenganJeneberang Provinsi Sulawesi Selatan. Disebut Bendungan Gerak karena pintu air bendungan dapat digerakkan dan dikontrol oleh operator mengikuti ketinggian (elevasi) air. Operator Bendungan Gerakan menetapkan dan mempertahankan elevasi air \pm 5 meter. Menurut mereka kebijakan ini mengingkari sifat asli dan alami Danau Tempe dan bertentangan dengan pengetahuan lokal yang diyakini warga lokal. Menurut warga, ikan hanya dapat berkembang biak dengan baik ketika mengikuti pola pasang surut. Pada saat air surut, ikan biasanya bertelur di dalam tanah dan pada saat air pasang, telur ikan menetas dan berkembang biak. Dengan mempertahankan elevasi air 5 meter, maka areal pesisir danau tidak dapat lagi dimanfaatkan sebagai areal pertanian begitupun di kedalaman air 5 meter, alat tangkap nelayan yang terbuat dari bambu (belle') tidak dapat dioperasikan karena tingginya hanya diperbolehkan 1.45 meter.

Secara administratif, Danau Tempe dibatasi dan dikelola oleh 3 (tiga) Kabupaten (Wajo, Soppeng dan Sidenreng Rappang). Di setiap kabupaten, setidaknya ditemukan 3 (tiga) rezim kepemilikan atau penguasaan lahan di Kawasan Danau Tempe, yaitu lahan ex-ornament milik pemerintah, milik pribadi (ongko) dan lahan bebas akses. Di masa lalu, semua areal lahan, baik perairan maupun daratan pinggiran merupakan areal bebas akses (open access) semua warga dan dikelola secara komunal. Warga lokal bebas memanfaatkan sumber daya alam di Danau Tempe dan siapapun tidak boleh menguasai atau memiliki lahan orang per orang. Berbeda di masa lalu, saat ini rezim pemilikan dan pola pemanfaatan sudah mengalami pergeseran dari rezim pemilikan komunal bergeser ke milik negara (ex-ornament), milik pribadi (ongko), dan sebagian masih daerah bebas (open acceses area).

Di lahan ex-ornament, masing-masing kabupaten mengatur pengelolaan Danau Tempe melalui peraturan daerah dengan mekanisme pelelangan. Di lahan milik pribadi, pemilik dapat menjual dan/atau menyewakan ke aktor lain. Di lahan bebas akses, pemanfaatannya bebas diakses secara bersama oleh warga lokal di 3 kabupaten. Nelayan dari Soppeng tidak dibatasi untuk menangkap ikan di Kabupaten Wajo dan Sidrap, sebaliknya Nelayan Wajo dan Sidrap tidak dibatasi untuk menangkap ikan di Kabupaten Soppeng.

Berdasarkan temuan penelitian lapangan, mekanisme pelelangan merupakan embrio terjadinya polarisasi sosial dan ekonomi di tingkat warga lokal. Warga yang memenangkan pelelangan, umumnya adalah nelayan besar yang disebut Pallawang (nelayan yang menangkap ikan di areal permanen yang dikuasai). Nelayan besar dicirikan oleh kepemilikan modal uang dan jaringan luas dengan pengusaha dan pemerintah daerah. Melalui pelelangan, pemerintah daerah memberikan hak akses ke pemenang lelang (Pallawang) untuk menguasai suatu lahan ex-ornament dalam masa waktu tertentu yang diharapkan berkontribusi sebagai sumber Pendapatan Asli Daerah.

Bagi nelayan tradisional yang disebut Pakkajalalla (nelayan kecil yang menangkap ikan secara berpindah-pindah), mekanisme ini dianggap merugikan dan cenderung meminggirkan mereka karena akan mempersempit areal penangkapan ikan di area bebas akses. Mereka menganggap bahwa mekanisme pelelangan hanya menguntungkan Pallawang yang memiliki modal ekonomi dan jaringan kedekatan dengan pemerintah daerah.

Temuan di lapangan menunjukkan adanya polarisasi sosial dan ketimpangan pendapatan antara nelayan besar (Pallawang) dengan nelayan tradisional (Pakkaja lalla). Secara ekonomi, di Danau Tempe mempraktikkan dualisme ekonomi. Di satu sisi, Pallawang mempraktikkan ekonomi modern yang dapat meraup keuntungan lebih besar dari hasil pengelolaan tanah ex-ornament. Pallawang dapat memperoleh pendapatan yang berkisar Rp 300000000 hingga Rp 500000000 per tahun. Di sisi lain, Pakkaja lalla mempraktikkan ekonomi subsistensi yang pendapatannya hanya cukup untuk kebutuhan konsumsi. Dengan menggunakan alat tangkap tradisional seperti jaring (lanra"), Pakkajalalla hanya memperoleh pendapatan sekitar Rp 100000 hingga Rp 300000 dalam kondisi normal. 
Secara sosial, Pallawang memperoleh reputasi sosial sebagai haji-haji yang dihormati dan ditokohkan di setiap even sosial, seperti pada saat peristiwa hajatan sosial di level warga. Setiap acara resmi pemerintah daerah, kecamatan dan desa/kelurahan, Pallawang selalu diprioritaskan sebagai tokoh masyarakat yang mewakili warga untuk mengikuti pertemuan atau rapat. Sementara Pakkajalalla, sangat jarang diundang untuk mengikuti acara-acara formal di desa dan kecamatan yang kemungkinan membicarakan soal-soal mekanisme pengelolaan Danau Tempe.

Mekanisme ini memicu potensi konflik antara Pallawang dan Pakkajalalla. Pallawang sering mencurigai bahkan menuduh Pakkajalalla mengganggu dan bahkan mencuri ikan dalam areal Pallawang. Pakkajalalla mengklaim bahwa, justru Pallawang sering memperluas batas ex-ornament dan menghalangi jalan perahu Pakkajalalla untuk mencari ikan di areal bebas. Pakkajalalla mengklaim bahwa mekanisme pelelangan ini sebetulnya tidak relevan diterapkan dalam mekanisme pengelolaan Danau Tempe. Menurut Pakkajalalla, pengelolaan dan pemanfaatan Danau Tempe harusnya dikembalikan dengan cara pengelolaan yang sama seperti pada masa lalu, yakni pengelolaan komunal. Pengelolaan komunal yang mereka maksud adalah pengelolaan dari, oleh dan untuk masyarakat masyarakat lokal, pengelolaan oleh masyarakat lokal yang diatur oleh tetua adat danau yang disebut macoa tappereng (tetua adat laki-laki yang disepakati warga untuk melaksanakan ritual adat di Danau Tempe, mengadili orang-orang yang melanggar aturan adat dan berkewajiban mendamaikan orang-orang yang berkonflik) dan pabijagae (tetua adat perempuan sebagai juru bicara yang membantu Macoa Tappareng dalam melaksanakan ritual adat).

Salah satu mekanisme pengelolaan komunal berbasis kearifan lokal di masa lalu yang masih dilestarikan sampai saat ini adalah larangan atau pantangan (pamali) menangkap ikan pada malam Jum'at. Kearifan lokal ini diyakini secara turun-temurun dapat memberikan keselamatan dan kesejahteraan bagi nelayan di Danau Tempe. Alasan lainnya adalah untuk memberikan kesempatan kepada ikan untuk berkembang biak pada malam Jum'at. Penerapan aturan informal ini masih eksis di Danau Tempe meskipun sudah mulai tergerus dengan kontestasi keyakinan dan pengetahuan modern. Penerapannya masih dapat dilihat, misalnya bagi nelayan yang melanggar akan dikenakan sanksi yang disebut Idosa, yaitu mekanisme sanksi dengan membayar denda berupa paket makanan ( 8 liter beras ketan (aruwa gantang berre" pulu) yang sudah diolah jadi sokko", 8 sisir pisang tertentu, dan 8 butir telur ayam). Pembayaran denda dilaksanakan dalam suatu upacara ritual maccera" tappareng yang dipimpin oleh Macoa Tappareng dan Pabijagae. Denda dibuat dalam bentuk sesajen yang dibawa ke danau sebagai tebusan dan pengakuan atas pelanggaran yang dilakukan oleh nelayan. Apabila yang bersangkutan tidak mampu membayar denda, maka perahunya disita oleh Macoa Tappareng, dan tidak dibolehkan untuk menangkap ikan selama beberapa hari.

Menurut sebagian besar nelayan kecil, pengelolaan Danau Tempe dengan mekanisme penetapan areal exornamen untuk dilelang sangat merugikan nelayan kecil. Mekanisme ini dianggap sulit dan tidak relevan diterapkan dalam realitas pengelolaan Danau Tempe untuk benar-benar menguasai ikan di dalam batas-batas administratif kabupaten dan batas-batas areal ex-ornament. Menurutnya, ikan pada dasarnya selalu bergerak dan tidak bisa diklaim sebagai milik suatu kabupaten atau milik suatu areal ex-ornament.

Fakta ini menunjukkan adanya kontestasi orientasi pengelolaan dan pemanfaatan Danau Tempe antara nelayan besar (Pallawang) dan nelayan tradisional (Pakkajalalla). Kontestasi ini mengindikasikan adanya perebutan sumber daya alam yang semakin eksploitatif. Aktor Pallawang dan Pakkajalalla sama-sama bersaing untuk mengelola dan memanfaatkan areal Danau Tempe untuk mendapatkan atau menangkap ikan sebanyak-banyaknya. Mereka saling mengklaim bahwa mereka memiliki hak akses dan kontrol terhadap pemanfaatan SDA di Danau Tempe (Said et al., 2019).

Temuan ini diceritakan oleh beberapa informan, seperti hasil wawancara penulis dengan salah seorang informan Pak AS, seorang nelayan tradisional di suatu sore di Dusun Salo Tengnga, Desa Pallimae, Kecamatan Sabbangparu Kabupaten Wajo dengan menanyakan: dimana titik lokasi Pallawang di Sabbangparu tahun 2017?; siapa yang menguasai dan siapa yang menggarap?; dan apakah nelayan tangkap tradisional bisa ikut serta dalam pelelangan?. 
Pak AS menjelasakan bahwa Di Kecamatan Sabbangparu ada 5 titik Pallawang, yaitu (1) Pallawang Jampue di Desa Ujung Pero dimenangkan oleh Pak NR (orang Sengkang) yang kerja adalah keluarganya, (2) Pallawang To Laddi di Desa Ujung Pero dimenangkan oleh Pak NR (orang yang sama yang menangkan Pallawang Jampue) dan dikerjakan sendiri, (3) Pallawang To Marujung di Desa Ujung Pero, namun dia tidak tahu siapa pemenangnya, (4) Pallawang Alau Salo di Desa Ugi yang dimenangkan oleh Pak UP dan dikerjakan oleh Pak AK (pekerja/buruh nelayan yang mempunyai alat tangkap dan perahu) dan (5) Pallawang Orai Salo" di Desa Pallimae yang dimenangkan oleh Pak UP dan dikerjakan oleh Pak HJ. Satu titik areal lahan dikuasai oleh Camat Sabbangparu (Camat yang sedang menjabat berwenang untuk mengelola 1 areal lahan ex-ornamen, yakni Pallawang Belle Barue yang luasnya ratusan hektar). Areal lahan ex-ornamen ini terletak di Desa Worong yang kemudian Pak Camat memberikan hak kepada salah seorang nelayan besar bernama Pak DH untuk mengelolanya dengan sistem bagi hasil.

Menurut Pak AS bahwa sebenarnya nelayan tangkap tradisional seperti Pak AK bisa saja ikut serta dalam pelelangan karena memiliki modal uang yang cukup, alat tangkap tersedia dan mempunyai anak buah dari keluarganya yang siap bekerja, akan tetapi Pak AK tidak mau pusing, dia dianggap tidak mempunyai pengalaman dan pendidikan, ke kantor saja malas dan malu katanya, jadinya Pak AK cukup menyewa atau bagi hasil saja dari Nelayan besar (Pallawang) yang bernama Pak UP. Justru Pak UP dianggap memiliki pergaulan yang luas, memiliki kedekatan emosional dengan pak Bupati, bahkan Pak UP pernah menjadi tim sukses pak Bupati pada PILKADA Wajo Tahun 2013 (Andi Burhanuddin Unru') dan sekarang, anak pak UP menjadi Calon Kepala Desa di Desa Ugi dan tahun 2014 juga menjadi calon legislatif DPRD Kabupaten Wajo dari Partai Golkar.

Berdasarkan hasil wawancara tersebut, dapat disimpulkan bahwa meskipun aturan pelelangan bersifat terbuka, namun ada beberapa faktor yang mempengaruhi, sehingga tidak semua nelayan mau dan dapat mengikuti pelelangan, diantaranya adalah faktor arus informasi yang tersebar dari panitia ke semua nelayan, kedekatan nelayan dengan panitia atau pemerintah daerah, pengetahuan aktor tentang mekanisme lelang dan pengalaman nelayan yang mengikuti pelelangan. Hal ini dapat dilihat melalui siapa saja yang memenangkan lelang dari tahun ke tahun maka akan memperlihatkan nama yang sering muncul dan berulang sebagai pemenang.

Temuan lain yang menarik adalah terkait kontestasi kepentingan antar aktor dalam Kebijakan Revitalisasi Danau Tempe Tahun 2016. Proyek ini dilakukan dengan pengerukan sedimen (lumpur) di Danau Tempe dan hasil kerukannya membentuk pulau-pulau di tengah danau. Ada sekitar 45 pulau yang direncanakan dengan lebar sekitar 100 hingga 200 meter dan panjang sekitar 500 hingga 900 meter (BBWS Pompengan-Jeneberang, 2016).

Narasi yang dibangun oleh negara tentang pentingnya revitalisasi adalah untuk memperbaiki fungsi dan kualitas daya tampung air di Danau Tempe ke titik normal dengan menambah volume tampungan sebesar 31.3 juta $\mathrm{m}^{3}$ (elevasi kurang lebih $5 \mathrm{~m}$ ), sehingga volume total menjadi $176.9 \mathrm{~m}^{3}$. Penambahan volume tampungan ini menurut narasi negara dapat berfungsi sebagai 1) irigasi pompa, 2) bangunan pengendali aliran sedimen; 3) pengendalian banjir pada sungai-sungai inlet dan outlet (BBWS Pompengan-Jeneberang, 2016). Sementara bagi nelayan, narasi dan tujuan yang diharapkan dari negara (pengetahuan modern) mustahil tercapai.

Berdasarkan wawancara dengan nelayan di lokasi pengerukan didapatkan informasi bahwa pengerukan menambah kedalaman tetapi mempersempit luas areal penangkapan ikan dengan adanya pulau yang dibangun di tengah danau. Sepengetahuan mereka, faktor utama penyebab pendangkalan danau adalah buangan sedimentasi yang mengalir dari hulu dan sungai ke danau. Jadi, mestinya yang direvitalisasi adalah abrasi sungai dan reboisasi lahan kritis hutan di hulu. Mereka meyakini bahwa proyek ini hanya sia-sia, tidak berhasil dan lama kelamaan mengalami pendangkalan lagi. Ditambahkan lagi, bahwa proyek ini merusak rumah (habitat) ikan, sehingga pengerukan ini hanya menguntungkan petani yang ada di hulu danau dan pada akhirnya merugikan nelayan di hilir. 
Dari sisi keputusan untuk merevitalisasi kondisi ekologis danau, ditemukan adanya kontestasi persepsi dan pengetahuan sebagai basis argumentasi untuk suatu produksi keputusan. Di sini, berlangsung kontestasi antara pengetahuan lokal nelayan versus pengetahuan modern (negara dan ahli). Dari sisi pengetahuan modern ditemukan bahwa narasi proyek dimaksudkan untuk berkontribusi merevitalisasi dan menormalisasi fungsi Danau Tempe sebagai tempat penampungan air dan pengendali banjir. Dari sisi pengetahuan lokal masyarakat, proyek ini justru berpotensi membunuh habitat ikan dan hanya menguntungkan petani di hulu dan secara bertahap merugikan nelayan yang menetap di kawasan ini. Sesungguhnya, nelayan mempercayai bahwa banjir yang selalu dialami tiap tahun bukan sebagai bencana alam melainkan sebagai berkah bagi nelayan. Menurut nelayan, banjir setiap tahun merupakan mekanisme alam di Danau Tempe dan memberikan berkah dengan melimpahnya jumlah tangkapan ikan setelah air surut. Selain itu, banyak kayu, bambu dan kelapa yang mengalir dari hulu akibat banjir yang dapat dimanfaatkan oleh warga lokal.

Nelayan mengklaim bahwa proyek revitalisasi menguntungkan kepentingan petani sebagai sumber irigasi bagi persawahan di hulu bukan untuk nelayan yang bermukim di kawasan dan pesisir Danau Tempe. Menurut nelayan, pengerukan berdampak pada berkurangnya areal penangkapan ikan dengan adanya pulau- pulau yang terbentuk dari timbunan urukan nantinya. Bisa jadi terjadi konversi lahan dari lahan penangkapan ikan menjadi areal destinasi wisata air atau areal pertanian oleh masing-masing pemerintah daerah.

Temuan tersebut memberikan penjelasan bahwa pilihan keputuasan atau orientasi pengelolaan Danau Tempe terutama dalam pengalokasian sumber daya alam terjadi ketimpangan atau asimetri kekuasaan antar aktor. Aktor negara dan ahli dengan pengetahuan modern dengan teknikalisasinya mengalahkan pengetahuan lokal warga dengan pengetahuan tradisionalnya secara turun-temurun dalam penentuan orientasi pengelolaan Danau Tempe. Padahal, dilihat dari aspek spasial Danau Tempe, sebetulnya Danau Tempe lebih tepat ketika orientasi kebijakannya difokuskan pada sektor perikanan ikan air tawar (fisheries oriented) bukan sebaliknya yang cenderung diorientasikan pada pengembangan pertanian (agricultural oriented). Data ini sekaligus mengonfiramasi kecenderungan ada proses marginalisasi bagi nelayan lokal sebagai stakeholder kunci di kawasan Danau Tempe.

Kesimpulan teori dalam penelitian ini memuat aspek ketimpangan kekuasaan dalam praktik pengelolaan sumber daya alam di Danau Tempe. Ketimpangan kekuasaan terbentuk ketika terjadinya ketidakseimbangan pemilikan aset kolektif dan variasi struktural dan posisional aktor (uang, pengetahuan, sosial, budaya dan reputasi sosial) yang dikapitalisasi melalui kemampuan mengakses lokasi-lokasi dan sumber-sumber daya sebagai bentuk akumulasi modal dalam penentuan keputusan dan mekanisme pengelolaan sumber daya alam Danau Tempe. Aktor yang sukses mengakumulasi modal lebih banyak selalu menjadi 'pemenang dalam memperebutkan nilai/manfaat/keuntungan dari pengelolaan dan pemanfaatan Danau Tempe. Sebaliknya, aktor yang kurang memiliki modal selalu menjadi "orang-orang kalah" dalam pengelolaan dan pemanfaatan Danau Tempe.

Sebagai refleksi teoritik dalam pengaturan pengelolaan dan pemanfaatan lahan di Danau Tempe dengan mekanisme teritorialisasi dan privatisasi menunjukkan bahwa pilihan kebijakan tata kelola atau kepengaturan pengelolaan Danau Tempe masih lebih berafiliasi atau mengadopsi tesis Hardin (1968) yang mengusulkan pengelolaan common ground yang disentralisasikan (centrralized-governance) dan melalui mekanisme pasar dengan kepemilikan pribadi (private-enterprize) sebagai domain utama dalam upaya-upaya mengatasi The Tragedy of The Common di Danau Tempe.

Pengelolaan yang disentralisasikan oleh negara dan privatisasi yang dikuasai pengusaha lokal (local comprador) dapat dicermati dengan dominannya negara (Pemerintah Daerah) untuk mengklaim dan mengontrol tanah ex-ornament sebagai tanah negara atau milik negara (state proverty). Setelah negara selesai mengklaim areal tanah ex-ornament sebagai tanah negara (negara dengan otoritasnya), langkah selanjutnya adalah melakukan teritorialisasi (pengkaplingan) berdasarkan batas-batas kabupaten dan batas-batas areal tanah ex-ornament. Kemudian tanah-tanah yang sudah diberi batas-batas dangan status tanah ex-ornament diserahkan ke pihak pengusaha lokal (swasta) yang menjadi nelayan besar atau Pallawang dengan mekanisme pelelangan (kontraktual) untuk dikelola dan dikuasai. Selanjutnya, Pallawang memanfaatkan momen ini untuk 
mengaktifkan dan memobilisasi sumber dayanya (modal) untuk mengakses dan mengontrol mekanisme pengelolaan dan pemanfaatan Danau Tempe.

Menariknya, karena Hardin (1998) menganggap bahwa cara ini merupakan strategi yang cukup efektif untuk mengatasi The Tragedy of The Common, akan tetapi cara Danau Tempe dikelola dengan mekanisme ini justru semakin meningkatkan kontestasi antar aktor, semakin meningkatkan eksploitasi SDA Danau Tempe dan semakin merentankan kondisi sosial, ekonomi dan ekologisnya secara berkepanjangan. Asimetri kekuasaan antara nelayan besar yang diuntungkan oleh kebijakan pemerintah daerah berhadapan dengan nelayan kecil yang memilik sumber daya lemah menyebabkan distribusi dan alokasi pengeloaan dan pemanfaatan Danau Tempe berlangsung eksklusif dan tidak adil. Implikasinya, nelayan besar memobilisasi sumber dayanya yang lebih besar (uang, pengetahuan, sosial, budaya dan reputasi sosial) untuk mendapatkan ikan sebanyak-banyakanya di areal ex-ornament Pallawang yang dimenangkan sebagai bentuk akumulasi modal. Nelayan besar juga memiliki akses dan kontrol bersama pemerintah daerah dalam mendominiasi penentuan keputusan, orientasi dan mekanisme pengelolaan Danau Tempe. Di sisi lain, nelayan kecil dengan keterbatasan akses dan kontrol terhadap lahan bebas akses terpaksa melakukan perlawanan-perlawanan kecil terhadap nelayan besar dengan mengganggu aktivitas pengelolaan lahan ex-ornament yang dikuasasi oleh nelayan besar. Dalam kondisi tertentu, nelayan kecil terpaksa menggunakan alat tangkap yang dilarang (illegal fishing) untuk bertahan hidup di saat tangkapan ikan semakin menurun. Antara nelayan besar dan nelayan kecil saling bersaing untuk menangkap ikan sebanyak-banyaknya menyebabkan sumber daya ikan di Danau Tempe semakin mengalami kelangkaan dan degradasi akibat over carrying capacity.

\section{KESIMPULAN}

Berdasarkan temuan penelitian tersebut, penelitian ini menyimpulkan proses berlangsungnya ketimpangan kekuasaan melalui ketidakseimbangan pemilikan aset kolektif (kekayaan, pengetahuan, dan jaringan sosial) antar aktor dalam pengelolaan sumber daya alam di Danau Tempe Sulawesi Selatan.

Kesimpulan penelitian ini memberikan kontribusi empirik pada proses kebijakan publik dan tata kelola barang publik yang mempertimbangkan kesetaraan partisipasi dan akses nilai/manfaat/keuntungan dari pengelolaan. Penelitian ini menyarankan kepada pengambil kebijakan untuk melakukan analisis stakeholder dalam proses permusan kebijakan pengelolaan Danau Tempe. Menyarankan pentingnya pemberdaayaan aktoraktor atau kelompok-kelompok rentan dalam pengelolaan Danau Tempe, seperti nelayan tradisional, yang memiliki keterbatasan sumber daya (powerless) sehingga diharapkan collaborative management dapat dipraktikkan dalam Pengelolaan Sumber Daya Alam secara bersama dan adaptif.

\section{DAFTAR PUSTAKA}

[BBWS] Balai Besar Wilayah Sungai Pompengan-Jeneberang. 2016. Laporan Akhir Detail Desain Pengerukan Danau Tempe Kabupaten Wajo. Jakarta (ID): PT INAKO Internasional Konsulindo.

[SLHI] Status Lingkungan Hidup Indonesia. 2012. Laporan Status Lingkungan Hidup Indonesia. Pilar Lingkungan Hidup Indonesia. Jakarta (ID): Kementerian Lingkungan Hidup Indonesia.

Armitage DR, Berkes F, Doubleday N. 2007. Adaptive Co-Management: Collaboration, Learning, and MultiLevel Governance. Canada (US): UBC Press, The University of British Columbia.

Armitage DR, Plummer R, Berkes F, Arthur RI, Charles AT, Davidson-Hunt IJ, Diduck AP, Doubleday NC, Johnson DS, Marschke M, et al. 2009. Adaptive co-management for social ecological complexity. Frontiers in Ecology Environment. 7(2): 95-102.

Berkes F. 2009. Review: Evolution of co-management: Role of knowledge generation, bridging organizations and sosial learning. Journal of Environmental Management. 90: 1692-1702.

Bodin O, Crona B. 2008. Community-based management of natural resources-exploring the role of social capital and leadership in a rural fishing community. World Development. 36: 2763-2779. 
Bodin O, Crona B. 2009. Review: The role of social networks in natural resource governance: What relational patterns make a difference?. Global Environmental Change 19: 366-374.

Bodin O, Crona B, Ernston H. 2006. Social networks in natural resource management: What is there to learn from a structural perspective?. Ecology and Society [Internet]. [diunduh 2020 Des 29]; 11(2). Tersedia pada: http://www.ecologyandsociety.org/vol11/iss2/resp2/.

Carlsson L, Sandström A. 2008. Network governance of the commons. International Journal of the Commons. 2(1): 33-54.

Hamidi. 2010. Metode Penelitian Kualitatif: Pendekatan Praktis Penulisan Proposal dan Laporan Penelitian. Malang (ID): UMM Press.

Hardin G. 1968. The tragedy of the commons. American Association for the Advancement of Science. 162(3859): 1243-1248.

Hardin G. 1998. Extensions of "the tragedy of the commons". American Association for the Advancement of Science, New Series. 280(5364): 682-683.

Ostrom E. 1990. Governing the Commons, the Institutions for Collective Action. Cambridge (GB): Cambridge University Press.

Said M, Kusumasari B, Baiquni M, Margono SA. 2019. The dynamics of social network structures and contestation in the collaborative management of Lake Tempe in South Sulawesi. Policy and Governance Review. 2(3): 217-231. doi: 10.30589/pgr.v2i3.106.

Sandström A, Rova C. 2010. Adaptive co-management networks: a comparative analysis of two fishery conservation areas in Sweden. Ecology and Society. XX(YY): ZZ.

Taylor B, Loe RCD. 2012. Conceptualizations of local knowledge in collaborative environmental governance. Geoforum. 43: 1207-1217.

Yamaki K. 2014. Network governance of endangered species conservation: A case study of Rebun Lady'sSlipper. Journal for Nature Conservation. 24: 83-92. doi: 10.1016/j.jnc.2014.10.004.

Yin RK. 2006. Studi Kasus (Desain dan Metode). Jakarta (ID): PT Raja Grafindo Persada. 